\title{
PENENTUAN HARI SIDANG DAN PEMANGGILAN PARA PIHAK SERTA \\ PENUNDAAN PELAKSANAAN KEPUTUSAN
}

TATA USAHA NEGARA

$\begin{array}{ll}\text { Nama Mahasiswa } & \text { : Ridhan Wifa Adli } \\ \text { Email } & \text { : ridhanwifaadli02@gmail.com } \\ \text { No BP } & 2010003600256\end{array}$

Universitas Ekasakti Padang

\section{A. Pendahuluan}

Pelayanan optimal, transparan dan efektif kepada masyarakat pencari keadilan adalah salah satu tujuan Pengadilan, dalam benak masyarakat pencari keadilan telah terbangun konstruksi pikiran tentang bagaimana berperkara di Pengadilan atau berapa biaya yang akan dihabiskan berurusan dengan Pengadilan bahkan mungkin konstruksi negatif pun kepada Pengadilan akan terbangun, saat terbentuk konstruksi ataupun ilustrasi pada masyarakat saat itulah telah terjadinya hukum dan fungsinya dalam masyarakat. Dapat dikatakan ilustrasi itu merupakan hal yang wajar, apalagi jika terjadi pada masyarakat awam segala macam ilustrasi negatif pada Pengadilan bahkan mungkin jika dipengaruhi oleh pemikiran ataupun media massa boleh jadi akan terjadi opini bahwa berurusan dengan Pengadilan sesungguhnya adalah nestapa.

Kemampuan individual pegawai Pengadilan, khusus lingkungan Pengadilan Agama dituntut untuk menghadapi konstruksi tersebut di atas, meskipun konstruksi tersebut berbentuk abstrak namun kemampuan pegawai harus lebih maju selangkah sebagai tindakan atau dapat menciptakan metode untuk menghadapi hal tersebut, dalam arti mau tidak mau pegawai harus siap, dalam hal ini maka kemampuan internal baik dalam bentuk ilmu pengetahuan ataupun sikap ( akhlakul karimah ) 
sesungguhnya haruslah telah lama terbentuk, jangan dan tidak bisa dipengaruhi oleh hal-hal yang membuat terpuruk nama Pengadilan. Jurusita ataupun jurusita Pengganti adalah orang yang pertama bertemu dengan para pencari keadilan, pihak pencari keadilan menggangap bahwa yang datang adalah petugas Pengadilan yang akan bersidang atas perkaranya, oleh karena anggapan ini maka pasti para pihak akan memberikan informasi-informasi tentang kasus yang dihadapinya.

Saat itu Jurusita / Jurusita Pengganti dituntut harus bisa bersikap selayaknya tugas Jurusita Pengganti sebagaimana diatur dalam Undang-undang, hindari dan jangan ada sikap Jurusita Pengganti seakan-akan bertindak mengadili para pihak saat memanggil. Jika Jurusita Pengganti melaksanakan tugasnya sesuai aturan akan dapat mengubah ilustrasi dan konstruksi pencari keadilan yang telah terbentuk, yang tadinya memberikan penilaian yang kurang baik akan berubah menjadi ilustrasi dan konstruksi positip, itulah makna orang yang pertama bertemu dengan para pihak. Sebaliknya jika tidak sesuai dengan aturan, maka ilustrasi dan konstruksi yang telah terbentuk akan yakinlah mereka bahwa sesungguhnya Pengadilan itu adalah nestapa dan menderita.

\section{B. Pembahasan}

Jurusita adalah petugas Pengadilan yang harus ada pada setiap Pengadilan, jika Pengadilan belum memiliki Jurusita maka harus diangkat Jurusita Pengganti. Untuk lingkungan Peradilan Agama semuanya telah ada petugas Jurusita Pengganti, meskipun belum semuanya ada Jurusita. Kata Jurusita terdiri dari dua kata yaitu Juru dan sita, dalam pengertian Juru diartikan sebagai orang yang pandai dalam sutau pekerjaan yang memerlukan latihan, kecakapan dan kecermatan. Pengertian tersebut dituntut untuk lebih dominan adalah skill atau kecakapan dalam melaksanakan tugas, sehingga apabila Jurusita dibekali dengan berbagai latihan dan pembekalan ilmu, 
maka itu adalah tuntutan sebagai seorang Juru bahkan harus dibekali dan dilatih. Jika kata Juru disambung dengan kata sita, maka pengertiannya adalah : Pegawai Pengadilan yang bertugas menyita barang-barang.

Dalam Kamus Hukum Jurusita adalah : "Petugas yang ditugaskan oleh Majelis Hakim Pengadilan adalah mempunyai kewajiban atau tugas yang sama ialah menjalankan Pengadilan, pemberitahuan dan semua surat-surat yang lain atau juga menjalankan perintah Hakim dengan segala keputusannya". Pengertian tersebut di atas sejalan dengan maksud "Justitie" yaitu : kehakiman, Peradilan dalam arti luas fungsi penguasaan untuk menegakan hukum dan kekuasaan Peradilan dalam Negara hukum. Pengangkatan Jurusita dan Jurusita Pengganti berpedoman pada UndangUndang Nomor 7 Tahun 1989 sebagaimana telah diubah dengan Undang-Undang Nomor 3 Tahun 2006 dan Undang-Undang Nomor 50 Tahun 2009, memperhatikan perubahan pasal khususnya pengangkatan Jurusita dan Jurusita Pengganti mendorong untuk lebih meningkatan kinerja dan pelayanan kepada pencari keadilan.

Adapaun pasal yang mengatur pengangkatan Jurusita dan Jurusita Pengganti adalah pasal 39 sebagai berikut:

1) Untuk dapat diangkat menjadi Jurusita, seorang calon harus memenuhi syaratsyarat sebagai berikut :

a) Warga negara Indonesia

b) Beragama Islam

c) Bertaqwa kepada Tuhan Yang Maha Esa

d) Setia kepada Pancasila dan Undang-Undang Dasar Negara RI Tahun 1945

e) Berijazah paling rendah Sekolah Menengah Umum atau sederajat

f) Berpengalaman sekurang-kurangnya 5 (lima) tahun sebagai Juru Sita Pengganti. 
2) Untuk dapat diangkat menjadi Juru Sita Pengganti, seorang calon harus memenuhi syarat-syarat sebagai berikut :

a) Syarat-syarat sebagaimana yang dimaksud dalam ayat (1) huruf a, b, c, d, dan e

b) Berpengalaman sekurang-kurangnya 5 (lima) tahun sebagai pegawai negeri pada Pengadilan Agama. Persyaratan tersebut diubah pada Undang-Undang Nomor 3 Tahun 2006 huruf (f) berpengalaman 3 (tiga) tahun sebagai Jurusita Pengganti dan ditambah huruf (g) sehat jasmani dan rohani. Dan ayat (2) tentang pengangkatan Jurusita Pengganti pada huruf (b) diubah menjadi : berpengalaman paling singkat 3 (tiga) tahun sebagai pegawai negeri pada pengadilan agama.

Perubahan kedua persyaratan tersebut pada UndangUndang Nomor 50 Tahun 2009 pada huruf (g) menjadi mampu secara rohani dan jasmani untuk menjalankan tugas dan kewajiban. Ada 2 (dua) persyaratan yang cukup signifikan berpengaruh pada Jurusita dan Jurusita Pengganti dalam melaksanakan tugasnya, dua persyaratan tersebut adalah beragama Islam dan mampu secara rohani dan jasmani untuk menjalankan tugas dan kewajiban.

Syarat beragama Islam merupakan azas personalitas Ke Islaman bagi pegawai Pengadilan Agama khususnya di Kepaniteraan, dalam arti bahwa azas personalitas Ke Islaman bukan sekedar menyentuh para pihak berperkara di Pengadilan 4 Agama namun persyaratan tersebut meliputi bagi yang ingin diangkat menjadi pegawai pada bidang ke paniteraan. Sedangkan persyaratan tentang mampu secara rohani dan jasmani untuk menjalankan tugas dan kewajiban merupakan aplikasi pada Jurusita dan Jurusita Pengganti saat berhadapan dengan para pencari keadilan ( sebagaimana disinggung pada uraian pendahuluan di atas ) kewajiban berarti dia ( Jurusita / Jurusita 
Pengganti ) harus berada dalam aturan dan tidak bisa berbuat diluar aturan yang telah ditetapkan, sadar ataupun tidak sadar jangan sampai terpancing dengan keluhankeluhan para pihak yang akhirnya memberikan keterangan melebihi tugas dan kewenangannya.

Tugas pokok Jurusita / Jurusita Pengganti berpedoman pada Undang-Undang Nomor 7 Tahun 1989 pasal 103 ( pasal ini tidak diubah oleh Undang-Undang Nomor 3 Tahun 2006 dan Undang-Undang Nomor 50 Tahun 2009 ), yaitu :

1) Juru Sita bertugas :

a) melaksanakan semua perintah yang diberikan oleh Ketua Ketua Sidang

b) Menyampaikan pengumuman-pengumuman, teguran-teguran, dan pemberitahuan penetapan atau putusan Pengadilan menurut cara-cara berdasarkan ketetuan undang-undang

c) melakukan penyitaan atas perintah Ketua Pengadilan; d. membuat berita acara penyitaan, yang salinan resminya diserahkan kepada pihak-pihak yang berkepentingan

2) Juru Sita berwenang melakukan tugasnya di daerah hukum Pengadilan yang bersangkutan. Setelah proses perkara didaftarkan di Pengadilan Agama dan Ketua Majelis telah menetapkan hari sidang selanjutnya diperintahkan kepada Jurusita / Jurusita Pengganti untuk memanggil para pihak berperkara pada hari dan jam yang telah ditetapkan. Panggilan adalah menyampaikan secara resmi (official) dan patut (properly) kepada pihak-pihak yang terlibat dalam suatu perkara di Pengadilan, agar memenuhi dan melaksanakan hal-hal yang diminta dan diperintahkan majelis hakim.

Surat panggilan atau dikenal juga dengan sebutan relaas, adalah akta autentik karena ditandatangani oleh pejabat dalam hal ini adalah Jurusita / Jurusita Pengganti. 
Pengertian tersebut sejalan dengan makna yang dapat difahami melalui pasal 388 HIR yaitu panggilan meliputi : panggilan sidang pertama kepada Penggugat / Pemohon dan Tergugat / Termohon, panggilan menghadiri sidang lanjutan kepada pihak-pihak atau salah satu pihak apabila pada sidang yang lalu tidak hadir, panggilan terhadap saksi yang diperlukan atas permintaan salah satu pihak dan penyampaian pemberitahuan, baik putusan tingkat pertama, tingkat banding maupun tingkat kasasi dan peninjauan kembali.

Relaas panggilan harus dalam bentuk tertulis, tidak dibenarkan dalam bentuk lisan, isi relaas panggilan diatur pada pasal 121 ayat (1) HIR yang meliputi nama yang dipanggil, hari dan jam serta tempat sidang, membawa saksi-saksi jika diperlukan, membawa segala surat-surat yang hendak diperlukan dan penegasan dapat menjawab gugatan dengan surat. Jurusita / Jurus sita Pengganti dalam melaksanakan panggilan harus memperhatikan dua azas, yaitu resmi dan patut.

Resmi adalah sasaran atau objek pemanggilan harus tepat menurut tata cara yang telah ditentukan oleh peraturan perundang-undangan yang berlaku. Patut maksudnya adalah kelayakan waktu antara pemanggilan dan waktu sidang, oleh karenanya harus memperhatikan tempat tinggal para pihak, tenggang waktu yang ditetapkan menurut aturan adalah tidak boleh kurang dari tiga hari kerja.

Pasal 122 HIR menyebutkan "Ketika menentukan hari persidangan, ketua menimbang jarak antara tempat dia atu tempat tinggal kedua belah pihak dari tempat pengadilan negeri bersidang dan kecuali dalam hal perlu benar perkara itu dengan segera diperiksa dan hal itu disebutkan dalam surat perintah, maka tempo antara hasil pemanggilan kedua belah pihak dari hari persidangan tidak boleh kurang dari tiga hari kerja”. Namun dalam Peraturan Pemerintah nomor 9 Tahun 1975 tentang Pelaksanaan Undang-undang nomor 1 Tahun 1974 tentang Perkawinan pasal 26 ayat (4) 
menyebutkan : "Panggilan sebagaimana dimaksud dalam ayat (1) dilakukan dan disampaikan secara patut dan sudah diterima oleh Penggugat maupun Tergugat atau kuasa selambat-lambatnya 3 (tiga) hari sebelum sidang dibuka”. Terdapat perbedaan antara HIR / R.Bg dengan PP tersebut halmana HIR menyebutkan 3 (tiga) hari kerja dan PP menyebutkan 3 (tiga) hari. Jika mengikuti HIR maka kesempatan pada pihak lawan untuk mempersiapkan diri dalam persidangan cukup lama karena menghitung hari kerja, apalagi sekarang hari Sabtu bukan hari kerja, sebaliknya mengikuti PP kesempatan menjadi singkat karena hari libur akan terhitung.

Panggilan disampaikan langsung kepada para pihak yang berperkara di tempat tinggal yang bersangkutan, namun apabila pihak menggunakan kuasa hukum, maka panggilan dipanggil melalui kuasa hukum yaitu dikantor kuasa hukum tersebut. Apabila pihak berperkara tidak dijumpai di tempat tinggalnya, maka panggilan disampaikan melalui Kepala Desa atau Kelurahan, sebagaiman diatur dalam pasal 390 HIRdan dalam Peraturan Pemerintah nomor 9 Tahun 1975 pasal 26 ayat (3) panggilan disampaikan kepada pribadi yang bersangkutan tidak dapat dijumpainya, panggilan disampaikan melalui lurah atau yang dipersamakan dengan itu.

pasal ini dapat ditafsirkan bisa jadi Kepala Desa, atau aparat Desa atau bisa juga ketua RT atau ketua RW, namun menurut Abdul Manan bahwa Mahkamah Agung memberikan petunjuk dalam beberapa pertemuan teknis yustisial yang diadakan selama ini bahwa RT bukan pejabat yang dimaksud dalam undang-undang, sehingga panggilan melalui RT tidak sah. Hal lain yang perlu diperhatikan adalah apabila terdapat salah pihak bertempat tinggal diluar wilayah hukum Pengadilan Agama tersebut, maka memerlukan bantuan pada Pengadilan Agama yang menjadi tempat tinggal pihak berperkara, dengan cara Ketua Pengadilan Agama mengajukan 
permohonan bantuan panggilan yang ditujukan pada Pengadilan Agama wilayah hukum pihak berperkara untuk dapat memanggil pihak tersebut.

Pengadilan Agama yang menerima bantuan panggilan dari Pengadilan Agama lain, diharapkan harus segera melaksanakan permintaan yang dimaksud dengan memerintahkan Panitera atau Jurusita ataupun Jurusita Pengganti untuk melaksanakannya. Untuk menghindari hal-hal yang tidak diinginkan, maka Panitera segera membuat buku kontrol khusus mencatat bantuan-bantuan panggilan maupun pemberitahuan, sekaligus dapat mengontrol pekerjaan Jurusita / Jurusita Pengganti.

\section{Penutup}

Berdasarkan uraian singkat di atas, maka dapat disimpulkan bahwa Jurusita / Jurusita Pengganti adalah salah satu pejabat di Pengadilan untuk dan bertanggung jawab terhadap pemanggilan yang harus berpedoman pada aturan perundangundangan dengan mengikuti tata cara pemanggilan yang terikat padanya, apabila pemanggilan dilaksanakan tanpa mengikuti tata cara tersebut, panggilan menjadi tidak sah dan berpengaruh pada persidangan.

\section{DAFTAR PUSTAKA}

Darmini Roza dan Laurensius Arliman S, Peran Pemerintah Daerah Di Dalam Melindungi Hak Anak Di Indonesia, Masalah-Masalah Hukum, Volume 47, Nomor 1, 2018. https://doi.org/10.14710/mmh.47.1.2018.10-21

Laurensius Arliman S, Peranan Metodologi Penelitian Hukum di Dalam Perkembangan Ilmu Hukum di Indonesia, Soumatera Law Review, Volume 1, Nomor 1, 201. http://doi.org/10.22216/soumlaw.v1i1.3346.

Laurensius Arliman S, Peran Badan Permusyawaratan Desa di Dalam Pembangunan Desa dan Pengawasan Keuangan Desa, Padjadjaran Journal of Law, Volume 4, Nomor 3, 2017. https://doi.org/10.15408/jch.v4i2.3433.

Laurensius Arliman S, Penanaman Modal Asing Di Sumatera Barat Berdasarkan Undang- Undang Nomor 25 Tahun 2007 Tentang Penanaman Modal, Supremasi Hukum, Volume 1, Nomor 1, 2018. http://dx.doi.org/10.36441/hukum.v1i01.102 .

Laurensius Arliman S, Memperkuat Kearifan Lokal Untuk Menangkal Intoleransi Umat Beragama Di Indonesia, Ensiklopedia of Journal, Volume 1, Nomor 1, 2018, https://doi.org/10.33559/eoj.v1i1.18.

Laurensius Arliman S, Perkawinan Antar Negara Di Indonesia Berdasarkan Hukum Perdata Internasional, Kertha Patrika, Volume 39, Nomor 3, 2017, https://doi.org/10.24843/KP.2017.v39.i03.p03.

Laurensius Arliman S, Partisipasi Masyarakat Di Dalam Pengelolaan Uang Desa Pasca UndangUndang Nomor 6 Tahun 2014 Tentang Desa, Jurnal Arena Hukum, Volume 12, Nomor 2, 2019, https://doi.org/10.21776/ub.arenahukum.2019.01202.5.

Laurensius Arliman S, Mewujudkan Penegakan Hukum Yang Baik Di Negara Hukum Indonesia, Dialogica Jurnalica, Volume 11, Nomor 1, 2019, https://doi.org/10.28932/di.v11i1.1831.

Laurensius Arliman S, Mediasi Melalui Pendekatan Mufakat Sebagai Lembaga Alternatif 
Penyelesaian Sengketa Untuk Mendukung Pembangunan Ekonomi Nasional, UIR Law Review, Volume 2, Nomor 2, 2018, https://doi.org/10.25299/uirlrev.2018.vol2(02).1587.

Laurensius Arliman S, Peranan Filsafat Hukum Dalam Perlindungan Hak Anak Yang Berkelanjutan Sebagai Bagian Dari Hak Asasi Manusia, Doctrinal, Volume 1, Nomor 2,2016.

Laurensius Arliman S, Ni Putu Eka Dewi, Protection of Children and Women's Rights in Indonesia through International Regulation Ratification, Journal of Innovation, Creativity and Change Volume 15, Nomor 6, 2021.

Laurensius Arliman S, Gagalnya Perlindungan Anak Sebagai Salah Satu Bagian Dari Hak Asasi Manusia Oleh Orang Tua Ditinjau Dari Mazhab Utilitarianisme, Jurnal Yuridis, Volume 3, Nomor 2, 2016, http://dx.doi.org/10.35586/.v3i2.180.

Laurensius Arliman S, Tantangan Pendidikan Kewarganegaraan Pada Revolusi 4.0, Jurnal Ensiklopedia Sosial Review, Volume 2, Nomor 3, 2020. 

